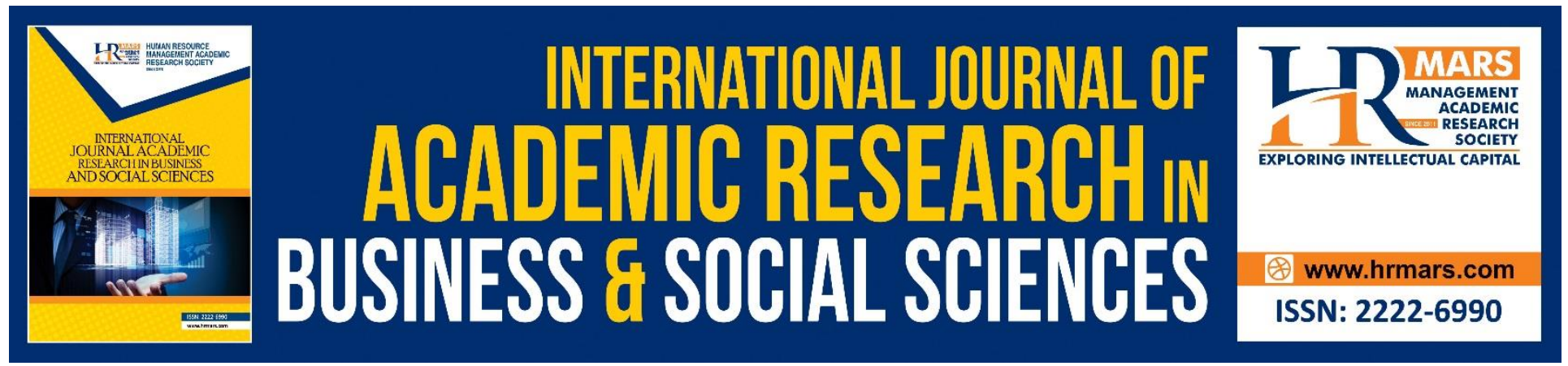

\title{
Proposed Methodology using Design Development Research (DDR) Improving Traceability Model with Test Effort Estimation
}

Mazidah Mat Rejab, Suriayati Chuprat, Nurul huda Firdaus Mohd Azmi

To Link this Article: http://dx.doi.org/10.6007/IJARBSS/v8-i8/4625

DOI: $\quad 10.6007 /$ IJARBSS/v8-i8/4625

Received: 09 July 2018, Revised: 21 August 2018, Accepted: 29 August 2018

Published Online: 08 September 2018

In-Text Citation: (Rejab, Chuprat, \& Azmi, 2018)

To Cite this Article: Rejab, M. M., Chuprat, S., \& Azmi, N. huda F. M. (2018). Proposed Methodology using Design Development Research (DDR) Improving Traceability Model with Test Effort Estimation. International Journal of Academic Research in Business and Social Sciences, 8(8), 686-699.

Copyright: (C) 2018 The Author(s)

Published by Human Resource Management Academic Research Society (www.hrmars.com)

This article is published under the Creative Commons Attribution (CC BY 4.0) license. Anyone may reproduce, distribute, translate and create derivative works of this article (for both commercial and non-commercial purposes), subject to full attribution to the original publication and authors. The full terms of this license may be seen at: http://creativecommons.org/licences/by/4.0/legalcode

Vol. 8, No. 8, August 2018, Pg. 686 - 699

Full Terms \& Conditions of access and use can be found at http://hrmars.com/index.php/pages/detail/publication-ethics 


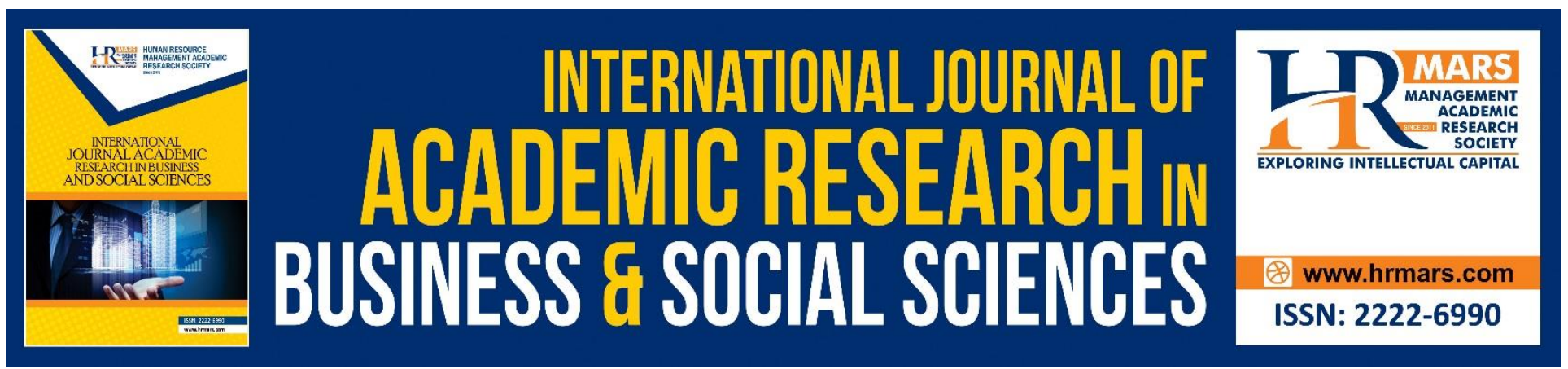

\title{
Proposed Methodology using Design Development Research (DDR) Improving Traceability Model with Test Effort Estimation
}

\section{Mazidah Mat Rejab, Suriayati Chuprat, Nurul huda Firdaus Mohd Azmi}

Advanced Informatics School (AIS) Universiti Teknologi Malaysia, Malaysia

\begin{abstract}
Software maintenance is an important activity in software development lifecycle. Any changes during the maintenance phase have impact on cost and time. Thus, to minimize cost and time, a test effort estimation is crucial. This research will produce an automate tool that can help the software manager or a maintainer to search for the coverage artefact before and after a changes request. Software quality engineer can determine the test coverage from new changes which can support in cost estimation, effort and schedule estimation. In an ongoing research project, we are developing software traceability model with test effort estimation. In this paper we described the development methodology which includes 3 major phases: requirement analysis, design and development, and finally the usability analysis of the proposed model.
\end{abstract}

Keywords: Software Traceability, Test Effort Estimation, Regression Testing, Software Changes, Nominal Group Technique, Fuzzy Delphi Method

\section{Introduction}

Software maintenance can be defined as the reformation of a software product after it been delivered to the end user. It is a broader activity that includes error rectification, performance improvement, enhancement of features and removal of obsolete capabilities. It is therefore not limited to source code but applicable to another component of software lifecycles such as revised requirements, improved of software design and software testing of the software system. Dealing with this border perspective within and across different work product is a difficult and challenging task. Bernett et. al (2000) expresses that "although software maintenance and evolution are portrayed for their high cost and slow speed implementation, yet they are inevitable activities." Mechanisms should be developed for assessing, controlling and make changes cost-effective during the maintenance phase.

In some projects, the maintenance cost can be higher. For example, weapons system, about 25 percent of the software life-cycle costs are for development the remaining 75 percent are maintenance (Stuebing, 1984). Also, the increasing number of software applications being deployed 
INTERNATIONAL JOURNAL OF ACADEMIC RESEARCH IN BUSINESS AND SOCIAL SCIENCES

Vol. 8, No. 8, August 2018, E-ISSN: 2222-6990 C 2018 HRMARS

may turn software maintenance into a major subindustry.

A high quality software needs vigorous software testing and starts as early as the beginning of software development which include static and dynamic testing. These testing activities need to be planned and manage properly. Each found defects need to be traced to the corresponding requirement. This practice is known as software traceability.

Traceability and getting updated coverage data before and after implementing a change is a great challenge. After a change, there is a different phenomenon that involves ripple effects and update of mapping links instantly. Also, the involvement of different work product makes it more difficult. Ibrahim (2006) stated the component relationship need to be broken down if they are too coarse. On the other hand, if they are too granular, it is difficult to reconstruct them into more recognizable software components. Therefore, such type of traceability approach must be adopted that can accommodate two granularities to deal with change effectively.

Software testing is a critical activity in software development as testing accounts for as much as high of $50 \%$ of total development efforts (Sharma,2013). A program is tested through two ways, one is by executing the source code and another is by examining the requirement. When errors are discovered retesting is a needed to the a modified program other related modules known as Regression Testing.

In regression testing, a source code is attempted by making the test cases from control flow graph as the execution of test cases is necessary for finding errors. On the hand regression testing is a better than average ramifications action of programming change and support. regression testing gives a run of the mill attestation that no supplementary goofs were showed up in the frameworks of putting in other issue or change of software (Kavitha \& Sureshkumar,2010). Nevertheless, regression testing may be over the top because this would require execution of all test cases present in the test suit.

Test effort estimation is that estimation of the testing size, effort, cost and timetable for software test project in an individual environment using the difference model, tool and technique(Bertolino,2007). Aranha \& Borba(2007) ensure the test effort is the extension of the effort spends on test activity and the effort spends on the debugging activity. In on-going research effort, we are developing software traceability model with test effort estimation during regression testing in software maintenance. This paper reports the methodology used in developing such model. The rest of this paper is organized as follow. In section 2, we described in detail the methodology used. We then explain a case study planned to evaluate the proposed model.

\section{Methodology}

In this section, we will describe methodology used in the development of the proposed software traceability model. The formulated methodology was based on the design developmental research (DDR) which is empirical by nature (Richey \& Klien, ,2007).. It emphasizes that instructional design

process is like scientific problem-solving processes.

Richey \& Klien (2007) state that using the DDR approach is very systematic which involving the process from the process of design and development and evaluation where it based on an empirical 
INTERNATIONAL JOURNAL OF ACADEMIC RESEARCH IN BUSINESS AND SOCIAL SCIENCES

Vol. 8, No. 8, August 2018, E-ISSN: 2222-6990 @ 2018 HRMARS

research. Other scholar support that using DDR approachable to develop measurement tool, product, and process. While Hevner et al (2004) and Ellis \& Levy (2008) pointed out that the DDR approach can be used as a guideline in the following research: -

- $\quad$ Produce of new theory in solving the problem

- $\quad$ Design and development of the new model in each field of study.

- $\quad$ Development of method and new process in implementation model or existing equipment.

Ellis \& Levy (2008) clearly stated that DDR approach is not a product, but it is closely linked to research, this criterion as below: -

- $\quad$ The study carried out to solve the problem

- $\quad$ The study carried out based on the literature and empirical study

- $\quad$ The study carried out to contribute to the body of knowledge.

Based on the criteria 1 these research was out to solve a problem. So, in the initial stage, we have identified the significant needs of test effort estimation in regression testing.

Using criteria 2, the research was carried out based on the literature and empirical study. Ellis \& Levy (2008) support that literature is important as will cover the needs, interest, and problem that lead to a research. Ven den Akker et al (2006) stated the same opinion that for research study, design and development process, it should involve the theoretically, exploration of the literature. Finally, for criteria 3 the study carried out to contribute to the body of knowledge. The contribution can be in many ways and is supported by Richey \& Klien, (2007) state that DDR is able to expand the approach and improve existing knowledge that lead to a new area of multiple research.

Figure 1 shows the conceptual framework of this study. The conceptual framework covers the topics of the study, model and theory that uses (theoretical framework) in the study and how this research was conducted (methodology framework and finally the output of the research.

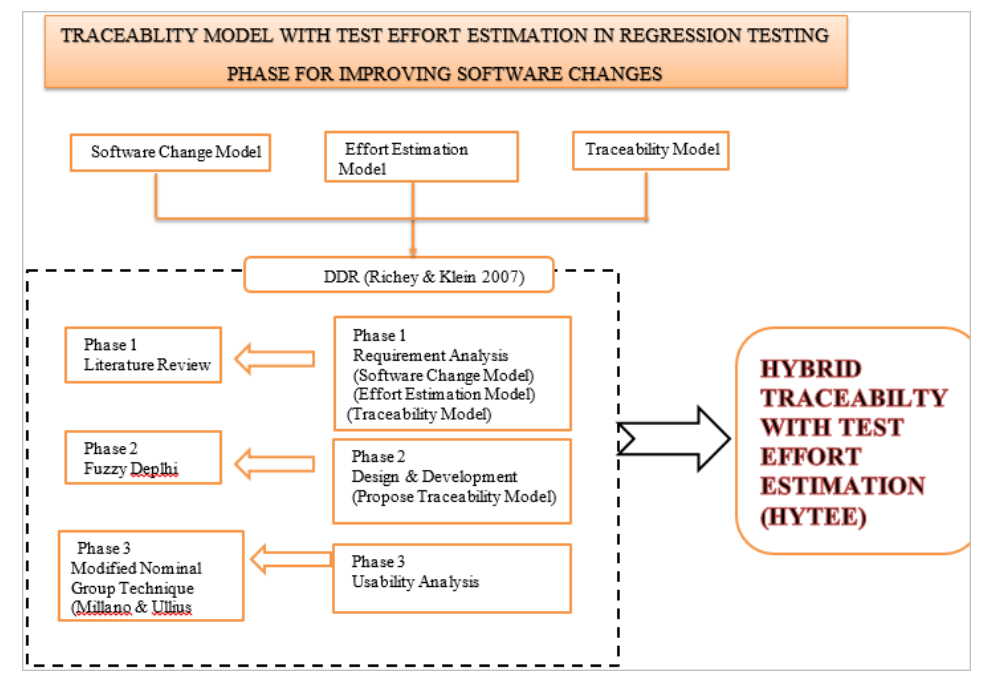

Figure 1: Conceptual Framework

According to DDR approach, this study will incorporate 3 main phases as outlined in Table 1 . We also proposed the method used in each phase, in which was adapted from book Design and Developmental Research: Emergent Trends in Educational Research (2013). 
INTERNATIONAL JOURNAL OF ACADEMIC RESEARCH IN BUSINESS AND SOCIAL SCIENCES

Vol. 8, No. 8, August 2018, E-ISSN: 2222-6990 @ 2018 HRMARS

Table 1: Design and Developmental Research Phase

\begin{tabular}{ll}
\multicolumn{1}{c}{ Phase } & \multicolumn{1}{c}{ Type of Developmental } \\
\hline Phase 1: Requirement Analysis & Literature Review \\
Phase 2: Design \& Development & Fuzzy Delphi Method (FDM) \\
Phase 3: Usability Analysis & Nominal Group Technique (NGT) \\
\hline
\end{tabular}

In DDR, for the first phase is the requirement analysis. The process involves in this study is the literature review. The result from this phase is the identified problem of the study and element in the proposed model. In the second phase, we will design and develop the proposed model and an expert opinion. The evaluation and verification process will be based on Fuzzy Delphi Method (FDM). The final phase is the usability analysis. It is planned to evaluate the usability of the proposed model. The usability evaluation process that will be used is the Nominal Group Technique (NGT). This study shows the three-phase of design and development the model. The details of each phases will be described in the following sections.

\section{A. Requirement Analysis Phase}

This phase begins with the understanding of the definition of change management, software maintenance, software traceability, test effort estimation and regression testing. Through the literature review, the research also gathered information on existing, traceability and effort estimation model can be used for maintenance task specifically on software changes and regression testing. A comparison was then made to existing model and approaches.

\section{B. Design and Development Phase}

Design and development phase is the most critical in DDR. In this we will design a hybrid traceability model based on existing traceability model and adding new features of test effort estimation. A new change management system is will also be developed to changes artifact and estimate the cost during regression testing phase.

This system will automate the change management process with test effort estimation during regression testing and updated traceability data. This updated information is a will be great source of help for the maintenance process during regression testing.

This model is built cross the functional requirement, design test, test case and source code of the software system. A traceability approach is used to establish links between software artifact.

For the design and development of the major component of this model, we will use FDM. This method consist of expert validation to assess, reject and adding component and element in the new proposed model Delphi Method is an approach that has been used and widely accepted to collect data for a study based on the validation expert in research (Hsu \& Sandford,2007). In this research, we used the diversity of Delphi technique in obtaining empirical data known as FDM.

This method by Kaufman and Gupta in the year 1988. FDM is a combination of the numbering of the fuzzy set method and Delphi itself improvement have been made in FDM as a measurement approach and know to be more effective and able to resolve issues that involves uncertainty (Murray \& Vangigch ,1985). FDM is a combination of the traditional method of Delphi (Classic) and fuzzy set theory (Fuzzy). The fuzzy set theory was introduced by an expert Zadeh (1965) in the field of 
mathematics in 1965 and it works as an extension of classical set theory where each element in a set are assessed based on the set of binaries (Yes or No). Fuzzy set theory assessment also allows gradual against each element under review. Ragin ( 2007) states that the value of numbering fuzzy consist of 0 to 1 or in the unit interval $(0,1)$. Delphi method on the other hand is a technique and approach that used to explore and gather opinion from groups of an expert in interviews (Muhammad, 2007) and ( Adler \& Ziglio, 1996). Delphi method is a method of decision making is done through several rounds of questionnaires to obtain concerning an issue or matter in the study (Linstone \& Turoff ,1975).

Delbecq et al (1975) state the method of Delphi is a method which can find the point of agreement and consensus of an expert in the systematic by using a set a questionnaire was developed based on the opinions of experts of its own. Hill \& Fowles (1975) pointed out that Delphi method capable of becoming a tool to make a forecast and expectation for an issue for the future based on the view of expert related to that issue.The conclusion of the expert opinion on the Delphi method proves that this method able to make a decision where the respondent involved consists of the who is experienced in that issue.

Therefore, a study based on Delphi method need researcher to perform direct interview to the respondents in order to obtain their view on an issue. The process to get the issue can also be carried out by using alternative methods such as doing literature search as pointed by work in Chang et al (2000) and Duffield (1993). Study by Powell (2003) claims that which stated that the Delphi method is very flexible this method is used to make a decision-based on the consensus of the expert group. However, there is also weakness in this method where Saedah (2008) stated that the reliability of the data is questionable if researchers fail to choose the right expert. She also added that another weakness possibility happens likely to occur is boredom by researcher and expert because iteration of Delphi as well as take a long time to finish that study.

These supported by are supported by Bojadziev (2007) whereby they claims that insisting that the most obvious flaws in this study involve Delphi method approach is its involves period of long-time study and iteration where it can leakage and loss data occurred and next to produce data that inaccurate and incomplete Thus, could lead the researcher to choose the minimum number of expert in conducting the research.

The selection of the minimum number of expert can be be insufficient as a small number of the expert will not be able to measure a big issue (Saedah, 2008). The opinion of total selected experts unlikely to represent the majority opinion of the experts. This view is also supported by the other scholar in which decision made by an expert is dependent on individual competency and it's very subjective (Bojadziev,2007).

Ho and Chen (2007) listed the weakness of Delphi method as follow:

- Iteration in Delphi to reach a consensus of expert will increase study time frame.

- Iteration in Delphi can contribute to the disruption of the continuity of the data obtained from the expert group.

- Higher cost occurred because the opinion from the expert involving several round and analysis had been done.

- Opinion among expert can only be obtained at a certain stage only. Any ambiguity shall not be considered, this situation will lead to misinterpretations between expert.

- The weakness in the process of analysis will also cause some expert opinion is not taken into the decision in reaching a consensus. 
INTERNATIONAL JOURNAL OF ACADEMIC RESEARCH IN BUSINESS AND SOCIAL SCIENCES

Vol. 8, No. 8, August 2018, E-ISSN: 2222-6990 @ 2018 HRMARS

Thus, based highlighted problem in Delphi method, we chose the FDM to be used in this research. The advantages of FDM as stated as above:

- It attempts to avoid boredom towards researcher and expert as attempts to reduce the cycle in Delphi.

- It seeks to avoid the loss data leakage by a researcher in that study.

- An expert could give a full opinion to ensuring a consistent and perfection.

- Take a look at undefined data that can be skip when running the research.

This argument is in line with Chang \& Lin (2000) which advises that FDM able to provide the following matters:

- It processes ambiguity in respect of item and content of the information respondents.

- Characteristics of individual participants can be explained.

In conclusion, FDM is able to use to obtain the consensus of an expert as the respondent based on the quantitative methods. There are many studies that applies FDM such as selection of technology for lubricants engineering (Hsu \& Kreng, 2010).; assessment of key indicators in determining the competency of executive management in the field of accounting (Liu, 2013).; selection strategy of problem solving in the field of communication (Jafari et al ,2008); determination of factors affecting socio-ecological area countryside (Lezama,2014); determination of the failure pipe (Ariavie \& Ovuwo, 2012).; the purposes of this aspect of the "riadhah ruhiyyah " to professionalism in the field of Islamic Education College (Habibah ,2014); the election system in choosing the vendor (Tahriri et al ,2014).; evaluation of Facebook (FB) for future curriculum (Nurulrabihah et al ,2015); assessment of capacity in the field of military combat shield (Cheng \& Lin, 2002).; development guideline in the psychology of learning for secondary schools (Nurulrabihah et al 2015); the determination of the activity of the elements for M-learning (Asra et al \& Siti Aisyah , 2014); the selection of the workers by the human resources department (Abduljabbar,2015).; development of the framework in marine engineering (Nazirah et al, 2015)

There are 2 main features in FDM which are Triangular Fuzzy Number and Defuzzification Process. Triangular Fuzzy Number is $m$ is made up of the value of the $m 1, m 2$, and $m 3$ where $m 1$ represents the value of the minimum (smallest value), representing the most reasonable value $\mathrm{m} 2$ (most plausible value) and $\mathrm{m} 3$ is referring to the maximum value (but there is value). All three values in the Triangular Fuzzy Number this can be seen in Figure 3.3 shows the graph that triangles mean against the value of triangular. Based on Figure 2 shows that all three of these values is also in the range of 0 to 1 and it coincided with fuzzy numbers (Ragin,2007).

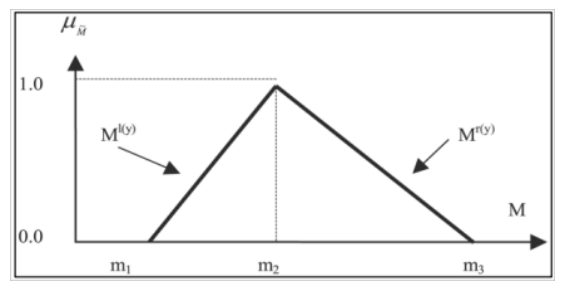

Figure 2: Graph triangle min against the value of triangular

In the ranking of Triangular Fuzzy Number, there are two terms that need to be followed for determining the acceptance of something the elements examined by the agreement of the expert which is the first requirement is to involve the value of threshold (d) and also the second requirement 
is the percentage Expert Group for some elements. The determination of the threshold value (d) this is according to a predetermined formula.

Both of conditions will explain in procedures to conduct this study using FDM in sub next topics. Defuzzification process refers to the process of determining the ranking for each construct, components, elements, issues, variables and variable sub that can be found in the study. The purpose of this process is to help the researcher to see requirement a variable and sub-variable that required. It can use to determine the ranking and priority for each element under review.

This ranking process will help produce the data according to the need based on the consensus of the expert as a respondent in the study. There is three formula that can be used in the defuzzification process. Researchers can select between three this formula to determine the ranking in their study. Three formulas in this process are as follows:

$$
\begin{array}{ll}
\text { i. } & \mathrm{A}_{\max }=1 / 3 *\left(\mathrm{a}_{1}+\mathrm{a}_{\mathrm{m}}+\mathrm{a}_{2}\right) \\
\text { ii. } & \mathrm{A}_{\max }=1 / 4 *\left(\mathrm{a}_{1}+2 \mathrm{a}_{\mathrm{m}}+\mathrm{a}_{2}\right) \\
\text { iii. } & \mathrm{A}_{\max }=1 / 6 *\left(\mathrm{a}_{1}+4 \mathrm{a}_{\mathrm{m}}+\mathrm{a}_{2}\right)
\end{array}
$$

In ranking the defuzzification process there is one condition that needs to be followed for the reception of expert groups for demonstrated something elements examined where the use of the median value of which is known as the alpha value-cut ( $\alpha$-cut) is used. Adler \& Ziglio (1996) argue that the number of a suitable expert in the Delphi Method was between 10 to 15 if there is a high level of consistency among expert. However, Jones \& Twiss, (1978) did suggest that to do research using Delphi Method, the number of experts involved is about 10 to 50 experts. In this context of the study, the researcher has appointed 12 people experts directly involved with the study.

\section{Usability Analysis Phase}

The next phase in DDR is usability analysis phase. Since the focus of this study is to reduce the cost during the regression testing phase for the traceability with effort estimation model, therefore it needs to have the usability analysis. Usability is defined as a measure of the ability of a product which is produced and developed and applied by the user of the product itself (Mack, \& Sharples, 2009). It can be seen from three aspects, namely effectiveness, efficiency and user satisfaction where every aspect is dependent on products produced (Milano \& Ullius, 1998). In this study, we are looking into the aspect user satisfaction which specializes in software testing to assess the usability of the developed model. Satisfaction aspect is referring to measurement based on the views of expert against usability model in term of in helping to reduce the cost and to save the time during software changes. According to Jeng \& Tzeng, (2012) the new product can be seen usability through the opinion and perceptions of the expert review in using the product. In usability phase, the opinion, and perception of the user which is from an industrial and academic background who had involved in software testing as a respondent have been collected through usability model questionnaire. All this data has been using the technique of analysis of Nominal Groups (NGT). NGT is a decision-making process in the form of small group discussions face to face (Aizat et al, 2006).The process of data collection can be in form of semi-structured and quantitative (Oneil et al ,1983), (Dobbie et al ,2004 ) and (Perry et al ,2004). 
INTERNATIONAL JOURNAL OF ACADEMIC RESEARCH IN BUSINESS AND SOCIAL SCIENCES

Vol. 8, No. 8, August 2018, E-ISSN: 2222-6990 @ 2018 HRMARS

This technique is a more directional approach to semi-quantitative because it combines a qualitative method. Because this technique starts with the process of "acceptance of the idea without assessment " (qualitative) that was later followed by the process of ranking or order of precedence idea (quantitative) (Oneil et al , 1983). However, it could be quantitative for the whole, if it is used as a technique to assess the usability product and the technique was known as NGT Modified (Dobbie et al ,2004 ). In the context of this study, researchers have been applying the NGT Modified to see usability of this model from user perception which is from user background of software testing. Another factor using this technique to find out percentage and user acceptance to this model. The NGT is aimed to against the idea and advise to the something issue (Perry et al , 2004). However, this technique is also used to measure capable product that has been developed. It was aligned with the study of Dobbie et al (2004) that modified to another step for looking usability of the model.

There are many studies that using a NGT to get data for research and to answer every question for issues. This technique is also seen used in the various field example education, social sciences, management, medicine, clinical engineering and so in. Based on the arguments of Delp et al (1977) states that there are six strengths of NGT technique: -

- The approach of this technique can balance the level of education and rank of the participants which the participants be allowed to speak based on their experience and knowledge to something issue.

- $\quad$ The implementation of this technique is in the group and face to face and it will give the opportunity to the participants to focus on an issue.

- $\quad$ This technique had a phase where each participant can write down their idea without criticized and interrupted by other participants

- $\quad$ Another phase to record all the ideas from the user.

- $\quad$ This technique has a discussion phase which aims to explain something in detail issues to avoid misunderstanding among participants of the study.

Other scholars were discussed about the strength of this technique which this technique also one of the approaches for problem-solving constructive and structured to achieve consensus in issues to produce one set of suggestion or priority solving [45],[47] and [50]. Thus, this technique requires each participant structure of each idea in evaluate the item [47], be allow participants of all group members, avoiding the influences of individuals who stand out from dominance discussion and to reduce stress individually to follow view from group (Aizat et al ,(2006), Oneil et al , (1983), Dobbie et al ,(2004), Lomax(1984). Although the discussion could get an explanation, any criticism is not allowed (Holtzapple et al, 2010).The NGT can get both positive and negative idea, generates creative ideas and comments that many compared to the method of review, less time and produced an honestly opinion among participants (Dobbie et al ,2004).It also encouraged the participants to make considerations about the overall item in the list idea and the idea expressed by the expert's group (Willam et al ,2006).

The implementation of the NGT, interaction in the group will control by facilitator (Perry et al , 2004). According to O'Neil \& Jackson (1983), the facilitator should be a natural in accepting the idea of the participant and capable of handling the information within the group. The facilitator should not interrupt or contribute an idea in the process of discussion. The facilitator is also not allowed to 
interpret the idea of someone, make a decision and should give participants time to think at the same time do not allow participants to challenge each other.

In term of validity and reliability, Williams (2006) state that the validity and reliability of this technique can be improved by specifying the criteria for the selection of members of the group, through preliminary study also determine of proper discussion questions. Group member of NGT, should really represent the group to ensure the validity of this technique (Lomax et al 1984). Expert is a respondent or subject of study directly involved in providing information and data in the usability evaluation phase. For the NGT, sample acting as a respondent for this study is a user from industrial and academic. Then the respondent is made up of software engineering lecturer involved in software testing syllabus.

Another respondent is from industrial are from software engineering field of work and focus on software testing as a software tester. The selection of respondent as user review is based on the scholar of Dalkey \& Helmer (1963) that the respondent selected shall have knowledge and insights in the context of the study. This opinion had a support from Swanson \& Holton, (2008) which also highlighted that the expert is categorized as their savvy, knowledgeable and skilled in a field under review.

Previous scholar Van and Delbecq (1975) addressing the number of specialist study involved in carrying out data collection approach NGT is about 5 to 10 people. However, Allen (2004) did suggest was a total of 9 to 12 experts involved in the study which is based on the NGT. Meanwhile, Harvey\& Holmes (2012) in turn insisted that the review teams the most ideal and best of 612 people. The polemic about the number of participants in the study this technique is something that is very subjective because it is depending on the result of the study expected. This argument was based on that past research that shows diversity among study participants study size Dobbie [14] involving 30 to 40 experts review, William et al (2006) a total of 92 people and study of Perry \& Linsley (2006) involving 36 people. The NGT is a process to generate and identify an issue. However, it can also be modified to see and evaluate the usability of a product developed (Dobbie et al ,2004). So, in this study, researchers have involved a total of 30 respondent which consist of industry and academic in software engineering background.

\section{Case Study}

In phase usability analysis using The Nominal Group Technique, the researcher selected the On-Board Automobile (OBA) project as a case study for this study. The software system was about 5k lines of code (LOC) with a complete documentation standard supporting MIL-STD-498. The code was written in $\mathrm{C}++$ and Java. In this phase we will do pre and post evaluation. The flow for this phase start from the respondent will run software of On-Board Automobile (OBA) and then try edit one line of code to find a bug line by line flow the step given. The $2^{\text {nd }}$ round for post study, the respondent will run the On-Board Automobile (OBA) and find the bug and fill out all the information that prototype needed and run the prototype to get a result.

\section{Conclusion and Future Work}

In this paper we have described the methodology used in developing the traceability model with effort estimation. The method was based the Design Development Research Richey \& Klein (2007). In the DDR method there are 3 phases to completed the research. In the first phase, we did a literature review to get an element in traceability and effort estimation to build the questionnaire of FDM and dummy prototype. In the second phase we build the questionnaire for FDM. Then we execute the 
INTERNATIONAL JOURNAL OF ACADEMIC RESEARCH IN BUSINESS AND SOCIAL SCIENCES

Vol. 8, No. 8, August 2018, E-ISSN: 2222-6990 @ 2018 HRMARS

FDM with expect validation. In the third phase we used the NGT for the usability analysis of the proposed model. We hope that this research will give some guidelines in using DDR method for similar research and finally contributes to the area of software engineering. For future work, we will present the results of this methodology that is the details of the proposed traceability model with effort estimation and the result of usability analysis.

\section{Acknowledgment}

The authors would like to thank Advanced Informatics School (AIS), Universiti Teknologi Malaysia (UTM) for the support of the resources.

\section{Corresponding Author}

Mazidah Mat Rejab. Advanced Informatic School (AIS), Universiti Teknologi Malaysia, 54100 Kuala Lumpur. (mazidah3@live.utm.my)

\section{References}

Abduljabbar, Z. (2015). Personnel Selection Using A Fuzzy Delphi Method. Electronic Scientific Journal. APRIORI. SERIES: natural sciences and engineering,3(31), 1-15.

Adler, M., \& Ziglio, E. (1996). Gazing into the oracle: the Delphi method and its application to social policy and public health. London: Jessica Kingsley Publishers.

Nasurdin, A. M., Osman I. \& Ahmad, Z. A. (2006). Pengantar Pengurusan. Kuala Lumpur: Utusan Publications \& Distributors Sdn. Bhd.

Allen, J., Dyas, J., \& Jones, M. (2004). Building consensus in health care: a guide to using the nominal group technique. British Journal of Community Nursing, 9(3), 110 -114.

Aranha, E., \& Borba, P. (2007, September). An estimation model for test execution effort. In Empirical Software Engineering and Measurement, 2007. ESEM 2007. First International Symposium on (pp. 107-116). IEEE

Ariavie, G.O. \& Ovuwo, G.C. (2012). Delphi Fuzzy Elicitation Technique in the Determination of Third Party Failure Probability of Onshore Transmission Pipeline in the Niger Delta region of Nigeria. J. Appl. Sci. Environ.Manage,16(1), 95 - 101.

Asra, M. R. T. L., Saedah, S. \& Siti Aisyah, H. (2014).Implementation Model of Mlearning Based Discovery Learning on Teacher Education. International Conference on Global Trends in Academic Research, June 2-3, 2014. Bali, Indonesia. Global Illuminators, Kuala Lumpur, Malaysia. 366-382.

Bennett, K. H., \& Rajlich, V. T. (2000, May). Software maintenance and evolution: a roadmap. In Proceedings of the Conference on the Future of Software Engineering (pp. 73-87). ACM.

Bertolino, A. (2007, May). Software testing research: Achievements, challenges, dreams. In 2007 Future of Software Engineering (pp. 85-103). IEEE Computer Society.

Bojadziev, G., \& Bojadziev, M. (2007). Fuzzy Set For Business, Finance and Management. Singapore: World Scientific Publishing Co. Pte. Ltd.

Chang, P. T., Huang, L. C., \& Lin, H. J. (2000). The Fuzzy Delphi method via fuzzy statistics and membership function fitting and an application to the human Resource. Fuzzy Sets and Systems,112(3), 511-520.

Cheng, C., \& Lin, Y. (2002). Evaluating the best main battle tank using fuzzy decision theory with linguistic criteria evaluation. European Journal of Operational Research,142, 174-186 
INTERNATIONAL JOURNAL OF ACADEMIC RESEARCH IN BUSINESS AND SOCIAL SCIENCES

Vol. 8, No. 8, August 2018, E-ISSN: 2222-6990 @ 2018 HRMARS

Dalkey, N. C., \& Helmer, O. (1963). An experimental application of the Delphi method to the use of experts. Management Science, 9(3), 458-467.

Delbecq, A. L., Van de Ven, A. H., \& Gustafson, D. H. (1975). Group techniques for program planning: a guide to nominal group and Delphi process. Glenview, IL: Scott, Foresman, and Co,

Delp, P., Thesen, A., Motiwalla, J., \& Seshardi, N. (1977). Systems tools for project tplanning. Bloomington, Indiana: International Development Institute.

DeWitt, N. A., Siraj, S., Rahman, M. N. A., Hussin, S. S., Alias, N., \& DeWitt, D. (2013). Design and Developmental Research: Emergent Trends in Educational Research.

Dobbie, A., Rhodes, M., Tysinger, JW. \& Freeman, J. (2004). Using a Modified Nominal Group Technique As a Curriculum Evaluation Tool, Family Medicine, 36(6), 402-406.

Duffield C. (1993) The Delphi Technique: a comparison of results obtained using two expert panels. International Journal of Nursing Studies, 30, 227-237.

Ellis, T. J., \& Levy, Y. (2008). Framework of problem-based research: A guide for novice researchers on the development of a research-worthy problem. Informing Science, 11.

Habibah @ Artini, R., Zaharah, H., Mohd Ridhuan, M.J., Ahmad Arifin, S., Saedah, S.\& Nurul Rabihah, M.N. (2014). Aplikasi Teknik Fuzzy Delphi Terhadap Keperluan Aspek „Riadhah Ruhiyyah" Untuk Profesionalisme Perguruan Pendidikan Islam. The Online Journal of Islamic Education (O-jIE), 2(2), $53-72$.

Harvey, N. \& Holmes, C.A. (2012). Nominal group technique: An effective method for obtaining group consensus. Iternational Journal of Nursing Practice, 18, 188

Hevner, A.R., March, S.T., Park, J. \& Ram, S. 2004. Design Science in Information Systems Research. MIS Quarterly Vol. 28 No. 1, pp. 75-105/March 2004.

Hill, K.Q., \& Fowles, J. (1975). The methodological worth of the Delphi forecasting technique. Technology and Forecasting and Social Change,7(2),179-192

Ho, Y.F. \& Chen, H. L. (2007). Healthy housing rating system. Journal of Architecture, 60, 115-136.

Holtzapple, M. T. dan Reece, W. D. (2010).Asas Kejuruteraan. Kuala Lumpur : Institut Terjemahan Negara Malaysia Berhad

Hsu, C. C., \& Sandford, B. A. (2007). The Delphi technique: making sense of consensus. Practical assessment, research \& evaluation, 12(10), 1-8.

Hsu, Y.L., Lee, C.H. \& Kreng,V.B. (2010). The application of Fuzzy Delphi Method and Fuzzy AHP in lubricant regenerative technology selection. Expert Systems with Applications, 37, 419-425.

Ibrahim, S. A Document-Based Software Traceability to Support Change Impact Analysis of ObjectOriented Software. 2006. Universiti Teknologi Malaysia: Kuala Lumpur.

Jafari, A., Jafarian, M., Zareei, A. \& Zaerpour, F. (2008). Using Fuzzy Delphi Method in Maintenance Strategy Selection Problem. Journal of Uncertain Systems, 2(4), 289-298.

Jeng, D. J.F., \& Tzeng, G.H. (2012). Social influence on the use of clinical decision support systems: Revisiting the unified theory of acceptance and use of technology by the fuzzy DEMATEL technique. Computers \& Industrial Engineering, 62(3), 819-828.

Jones, H. \& Twiss, B.L. (1978). Forecasting Technology For Planning Decisions. New York: Macmillan

Kaufmann, A., \& Gupta, M. M. (1988). Fuzzy mathematical models in engineering and management science. Elsevier Science Inc.

Kavitha, R., \& Sureshkumar, N. (2010). Test case prioritization for regression testing based on severity of fault. International Journal on Computer Science and Engineering, 2(5), 1462-146.

Lezama, A.P.S., Arroyo, J.C. \& Hernandez, C.A. (2014). Applying the Fuzzy Delphi 334 Method fordetermining socio-ecological factors that influence adherence to mammography screening 
INTERNATIONAL JOURNAL OF ACADEMIC RESEARCH IN BUSINESS AND SOCIAL SCIENCES

Vol. 8, No. 8, August 2018, E-ISSN: 2222-6990 @ 2018 HRMARS

in rural areas of Mexico. Methodological Issues. Cad. Saúde Pública, Rio de Janeiro,30(2), 245258

Linstone, H. A., \& Turoff, M. (1975). The Delphi method: Techniques and applications.Boston, MA: Addison-Wesley

Liu, W.K. ( 2013). Application of the Fuzzy Delphi Method and the Fuzzy Analytic Hierarchy Process for the Managerial Competence of Multinational Corporation Executives. International Journal of e-Education, e-Business, e-Management and e-Learning,3(4), 313-317.

Lomax, P. \& McLeman, P. (1984). The uses and abuses of nominal group technique in polytechnic course evaluation. Studies in Higher Education, 9(2), 183-190

Mack, Z., \& Sharples, S. (2009). The importance of usability in product choice: A mobile phone case study. Ergonomics, 52(12), 1514-1528.

Milano, M. \& Ullius, D. (1998). Designing powerful training, The Sequential-Iterative Model. JosseyBass/Pfeiffer. A Wiley Company, San Francisco.

Muhammad Imran, Y. (2007). The Delphi Technique. Essays in Education, 20, 80-89.

Murray, T., Pipino, L., \& Vangigch, J. (1985). A pilot study of Fuzzy set modification of Delphi. Human System Management, 5(1), 6-80.

Nazirah, M. A., Abdullah, H.O., Shuib, R., Rodzah, Y., Siti Zainon, M., Tuan Mohammad, T.Y., Wan Muhammad Aizat, W.A., Mohd Farid Al Azmi, I. \& Mohd Naszrie, R. (2015). Fuzzy Delphi for Marine Space Stakeholder Framework Development: An Analytical Literature Review. WCS-CE - The World Cadastre Summit, Congress \& Exhibition. Istanbul, Turkey, 20 -25 April 2015, 1-21

Nurulrabihah, M.N., Saedah, S., Mohd Ridhuan, M.J., Zaharah, H.\& Ahmad Arifin, S.(2015). Design Of Guidelines On The Learning Psychology In The Use Of Facebook As A Medium For Teaching \& Learning In Secondary School.TOJET: The Turkish Online Journal of Educational Technology,14(1), 39-44.

O'Neil, M.J. \& Jackson, L. (1983). Nominal Group Technique: A process for initiating curriculum development in higher education, Studies in Higher Education, 8(2),129- 138.

Perry, J. \& Linsley, S. (2006). The use of the nominal group technique as an evaluative tool in the teaching and summative assessment of the inter-personal skills of student mental health nurses. Nurse Education Today, 26, 346-53.

Powell, C. (2003). The Delphi technique: myths and realities. Journal of Advanced Nursing, 41(4), 376382.

Ragin, C. C. (2007). Qualitative comparative analysis using fuzzy sets (fsQCA). In Configurational comparative analysis. London: Sage Publications.

Richey, R., \& Klien, J. (2007). Design and development research: Method, strategies and issues. London: Erlbaum

Saedah, S. (2008). Kurikulum Masa Depan. Kuala Lumpur: Universiti Malaya.

Sharma, A. (2013, December). Test effort estimation in regression testing. In Innovation and Technology in Education (MITE), 2013 IEEE International Conference in MOOC (pp. 343-348). IEEE.

Stuebing, H. G. (1984). A software engineering environment (SEE) for weapon system software. IEEE transactions on software engineering, (4), 384-397.

Swanson, R.A. \& Holton, E.F. (2008). Foundations of Human Resource Development. Berrett-Koehler Publishers, Inc

Tahriri, F., Mousavi, M., Haghighi, S.H. \& Md Dawal, S.Z. (2014). The application of fuzzy Delphi and fuzzy inference systemin supplier ranking and selection.Springer. J Ind Eng Int, 10(66), 1-16. 
INTERNATIONAL JOURNAL OF ACADEMIC RESEARCH IN BUSINESS AND SOCIAL SCIENCES

Vol. 8, No. 8, August 2018, E-ISSN: 2222-6990 @ 2018 HRMARS

Van de Ven, A. and Delbecq, A.L. (1971). Nominal versus Interacting Group Processes for Committee Decision-Making Effectiveness. Academy of Management Journal, 14(2), 203 -212

Ven den Akker J., Gravemeijer K., McKenney S. \& Nievee N. (2006). Educational Research Design. Routledge. New York

Williams, P. L., White, N., Klem, R., Wilson, S. E., \& Bartholomew,P. (2006). Clinical education and training: using the nominal group technique in research with radiographers to identify factors affecting quality and capacity. Radiography, 12(3), 215-224

Zadeh L.A. (1965). Fuzzy sets and systems, System Theory (Fox J., ed.), Microwave Research Institute Symposia Series XV, Polytechnic Press,Brooklyn, NY, 29- 37. Reprinted in International journal of General Systems, 17, 1990, 129-138. 